\title{
Perception and Satisfaction on the Online Teaching in OB/GYN Course during COVID-19
}

\author{
Omar A. Fatani ${ }^{1 *}$, Waleed K. Mijlad ${ }^{1}$, Malak M. Al-Hakeem ${ }^{2}$ \\ ${ }^{1}$ College of Medicine, King Saud University, Saudi Arabia \\ ${ }^{2}$ Professor, College of Medicine, Department of Obstetrics and Gynaecology, King Saud University, Saudi Arabia
}

\begin{abstract}
DOI: $10.36348 /$ sijog.2021.v04i01.002
| Received: 02.01.2021 | Accepted: 15.01.2021 | Published: 16.01.2021
\end{abstract}

*Corresponding author: Omar A. Fatani

\section{Abstract}

Introduction: The pandemic of Coronavirus has not only affected the lives of humans, but it also affected health education and training programs. With the implementation of social distancing, all the classes in which there's face to face communication has stopped because of the COVID-19 pandemic. This study aimed to assess the perception and satisfaction of the online teaching in obstetrics and gynecology course in 2020 during the COVID-19 crisis. Methods: 92 students at King Saud University, Riyadh, Saudi Arabia have been involved in the study. We had two groups of students; first group took the lessons traditionally. The second group had taken the lessons via online methods. Results: There was a significant difference between the groups regarding satisfaction about e-learning, score and resource availability. Being more satisfied in groups who had online teaching was more than the other group. It was noted no difference in skills or performance between students of e-learning and those of traditional learning groups. However, students from different groups showed different impressions about the enjoyability of sessions, considering e-learning as a tool for future learning, limitation of student-teacher interaction during the course. Conclusion: E-learning had a significant positive impact on society during the Covid-19 pandemic, and future study systems may change radically accordingly.

Keywords: COVID-19, OB/GYN, Satisfaction, Perception.

Copyright $\odot 2021$ The Author(s): This is an open-access article distributed under the terms of the Creative Commons Attribution 4.0 International License (CC BY-NC 4.0) which permits unrestricted use, distribution, and reproduction in any medium for non-commercial use provided the original author and source are credited.

\section{INTRODUCTION}

The pandemic of Coronavirus has not only affected the lives of humans, but it also affected the health education and training residents. With the implementation of social distance, all the classes in which there is face to face communication has stopped because of the COVID 19 pandemic [1]. Many schools and universities were closed, students were sent back to their homes, and self-isolation was applied. The graduation ceremony has been canceled, as well as some classes and tests. They also postponed university research programs [2]. Many studies discussed the importance and effectiveness of e-learning. Many universities around the world are supporting it as a method of teaching and it's becoming widely valued by learners. There are many reasons for its acceptance in general; few of them are workable for the students: easy to use, flexibility and good environmental control [3]. Because of the sudden appearance of COVID-19, many faculty members face adversities, such as a lack of experience in teaching on the internet, technology educating teams or early preparation [4]. There was a study done in Ho Polytechnic, Ghana, the research results showed that most of the students believed that elearning is a creative idea that has to be encouraged. But they discovered that there were some problems, such as employees' bias to those who learned in a traditional way against those who studied online. It has also been recognized that hybrid learning, a mixture of learning on the internet and face to face learning, is the preferred style of learning for the learners [5]. A study in Indonesia's open university, Taiwan branch, showed that the perception of face to face learning was greater than e-learning in terms of contentment, interaction and social presence [6]. Another study done in Indonesia (Airlangga University) showed that $85 \%$ are happy with online teaching because they believe that online teaching is enjoyable and accessible and makes materials easy to accommodate [7]. A study was conducted in the Kingdom of Saudi Arabia on two universities to assess their understanding of the current 
Omar A. Fatani et al; Sch Int J Obstet Gynec, Jan. 2021; 4(1): 6-10

online learning systems. The results showed that a lot of students $(72 \%)$ agreed or highly agreed that online learning systems increased their perception that is required for the teaching process. Most of the students (71\%) agreed or highly agreed that utilizing online learning systems raises their productivity faster. The outcome as well confirmed that $60 \%$ of the respondents were satisfied or highly satisfied in dealing with online learning systems. While $23 \%$ of them disagree or highly disagree about their satisfaction in dealing with online learning systems [8]. A study conducted in the Philippines on three universities to assess the effect of online systems, the results showed that $94 \%$ of the respondents highly agreed that online learning gives elasticity in the process of education. Furthermore, $81 \%$ have a huge thought that online learning aids the students in realizing the lessons in a perfect way, enhancing how the faculty communicate with the students and using internet resources will save the sessions time [9].

\section{METHODS}

The present study is part of a cross-sectional descriptive study on medical students who studied Obstetrics and gynecology course in 2020 during COVID-19 crisis at King Saud University, Riyadh, Saudi Arabia. The approval of the ethical committee was obtained from King Saud University. The data collected using self-administered anonymous surveys (online) due to current quarantine and precautionary regulations. Participation was on a voluntary basis. The questionnaire was administered to the subjects by technology facilities via email, and WhatsApp messages to participate in this study. All students were provided with full information about the study and how to access the online link, which is created using google forms tool to standardize the process and reduce the number of possible mistakes during data collection. The Yamane formula for population proportion assumes normal distribution at $95 \%$ confidence level, therefore it can be considered suitable for determining an appropriate sample size. With a margin of error $8.5 \%$ and population size of 275 , this results in: The minimum sample size of medical students who studied Obstetrics and gynaecology course in 2020 at King Saud University is 89 participants.

\section{Statistical Analysis}

Data was analyzing through Statistical Package for the Social Sciences (SPSS) version 23 and the IBM Excel spreadsheets to explore the perception and satisfaction on the online teaching in $\mathrm{OB} / \mathrm{GYN}$ course.

\section{RESULTS}

Along with the dramatic worldwide effects of COVID-19 pandemic on health practice, science and administrative aspects, the consequent home isolation and social distancing affect also medical education and medical student satisfaction of education programs.

Medical education is a field that needs practical, clinical and laboratory teaching along with theoretical teaching, and loss of either might result in sever disadvantages.

In this study, participants were ranging between 22 and 25 years of age, average 23.6 (SD \pm 0.7 ). Male-to-female ratio was 4.4 to 1 . All female students were taking traditional teaching courses, while $44 \%$ of male students have taken online course. There were no difference in traditional course group and online course group regarding distribution of GPA categories or the types of devices used (Table-1).

\begin{tabular}{|c|c|c|c|c|}
\hline \multicolumn{5}{|c|}{$\begin{array}{l}\text { Table1: distribution of gender, GPA categories and devices used in education, through } \\
\text { sample and among groups of teaching styles. }\end{array}$} \\
\hline \multirow[b]{2}{*}{ Characteristics } & \multirow{2}{*}{$\begin{array}{l}\text { All Participants } \\
\text { Frequency }(\%)\end{array}$} & \multicolumn{2}{|c|}{ Groups } & \multirow[b]{2}{*}{ p-value } \\
\hline & & $\begin{array}{l}\text { Online Course } \\
\text { group }\end{array}$ & $\begin{array}{l}\text { Traditional Course } \\
\text { Group }\end{array}$ & \\
\hline \multicolumn{5}{|l|}{ Gender } \\
\hline Female & $17(18.5)$ & 0 & 17 & \multirow{2}{*}{$<0.001^{*}$} \\
\hline Male & $75(81.5)$ & 33 & 42 & \\
\hline \multicolumn{5}{|l|}{ GPA categories } \\
\hline$>4.5$ & $8(8.7)$ & 8 & 15 & \multirow{4}{*}{$0.163 \#$} \\
\hline $3.5-3$ & $26(28.3)$ & 4 & 4 & \\
\hline $4-3.51$ & $35(38)$ & 13 & 13 & \\
\hline $4.5-4.01$ & $23(25)$ & 8 & 27 & \\
\hline \multicolumn{5}{|l|}{ Devices used } \\
\hline Desktop & $2(2.2)$ & 0 & 2 & \multirow{4}{*}{$0.283 \#$} \\
\hline Laptop & $50(54.3)$ & 21 & 29 & \\
\hline Mobile & $3(3.3)$ & 0 & 3 & \\
\hline Tablet & $37(40.2)$ & 12 & 25 & \\
\hline
\end{tabular}


Omar A. Fatani et al; Sch Int J Obstet Gynec, Jan. 2021; 4(1): 6-10

Surveying the preference of participating students regarding the best style of medical education on which to continue for after COVID-19 pandemic ending revealed no difference between either group.
However, the majority of students in either groups prefer to combine both traditional and online teaching (Table-2).

Table 2: Differences in frequency of responses about preference of teaching style after the end of COVID-19

\begin{tabular}{|l|c|c|c|c|}
\hline \multirow{2}{*}{ Group } & \multicolumn{2}{|c|}{ Preference after end of COVID19 pandemic } & Both & p-value \\
\cline { 2 - 5 } & E-learning & Traditional classes & 17 & $0.194^{*}$ \\
\hline Online Course Group & 8 & 8 & 35 & $*$ \\
\hline Traditional Course Group & 6 & 18 & B \\
\hline
\end{tabular}

*Two-sided p-value was calculated by Pearson Chi-Square

Surveying the general impressions of students regarding E-learning, they noted no difference in skills or performance between students of e-learning and those of traditional learning groups. However, students from different groups showed different impressions about appropriateness of sessions to level of learning, sessions being interesting or enjoyable, considering elearning as a tool for future learning, limitation of student-teacher interaction during the course, or coverage of the required objectives of the sessions. The role of educational technology team was not equal. There are significant differences among groups regarding impression of student towards getting experience or having support from educational technology team. Notably, the majority of online group described services of educational technology team as neutral. There is an agreement between groups about lack of self-discipline and learning materials while depending on e- learning courses in home isolation. However, there is difference in the students' impression about the availability if learning environment in home isolation, without clear pattern of that difference. Surveying students' responses revealed agreement between groups regarding restriction of body language and the difference between courses modality in satisfaction. There is no clear pattern of that agreement. However, responses differ between groups regarding the availability of network. In the online MINICEX test there is significant agreement regarding appropriateness for each objective (Table-3).

\begin{tabular}{|c|c|c|c|c|c|c|c|}
\hline \multirow[b]{2}{*}{ Group } & \multicolumn{6}{|c|}{ Responses (n) } & \multirow{2}{*}{$\begin{array}{c}\text { P- } \\
\text { value* }\end{array}$} \\
\hline & $\begin{array}{c}\text { Strongly } \\
\text { Agree }\end{array}$ & Agree & Neutral & Disagree & $\begin{array}{l}\text { Strongly } \\
\text { Disagree }\end{array}$ & $\begin{array}{c}\text { Not } \\
\text { Applicable }\end{array}$ & \\
\hline \multicolumn{8}{|c|}{ The sessions were appropriate for the level of learning } \\
\hline Online & 12 & 15 & 5 & 0 & 1 & 0 & \multirow{2}{*}{$<0.001$} \\
\hline Traditional & 3 & 11 & 7 & 0 & 0 & 38 & \\
\hline \multicolumn{8}{|c|}{ The sessions were interesting and enjoyable } \\
\hline Online & 11 & 12 & 5 & 4 & 1 & 0 & \multirow{2}{*}{$<0.001$} \\
\hline Traditional & 0 & 7 & 8 & 6 & 0 & 38 & \\
\hline \multicolumn{8}{|c|}{ Considering e-learning as a better teaching tool and preferred it for future learning } \\
\hline Online & 10 & 3 & 4 & 15 & 1 & 0 & \multirow{2}{*}{$<0.001$} \\
\hline Traditional & 6 & 15 & 14 & 14 & 10 & 0 & \\
\hline \multicolumn{8}{|c|}{ E-learning has limited student-teacher interaction } \\
\hline Online & 5 & 16 & 3 & 9 & 0 & 0 & \multirow{2}{*}{0.024} \\
\hline Traditional & 25 & 13 & 7 & 12 & 2 & 0 & \\
\hline \multicolumn{8}{|c|}{ Noted differences in skills and performance of students of different groups } \\
\hline Online & 14 & 12 & 5 & 2 & 0 & 0 & \multirow{2}{*}{0.485} \\
\hline Traditional & 33 & 14 & 8 & 2 & 2 & 0 & \\
\hline \multicolumn{8}{|c|}{ Online session coverage of the required objectives for the sessions } \\
\hline Online & 12 & 13 & 4 & 3 & 1 & 0 & \multirow{2}{*}{$<0.001$} \\
\hline Traditional & 3 & 14 & 2 & 0 & 2 & 38 & \\
\hline \multicolumn{8}{|c|}{ Getting online teaching experience from educational technology teams } \\
\hline Online & 2 & 7 & 22 & 2 & 0 & 0 & \multirow{2}{*}{$<0.001$} \\
\hline Traditional & 3 & 6 & 5 & 7 & 0 & 38 & \\
\hline \multicolumn{8}{|c|}{ Support from educational technology teams } \\
\hline Online & 0 & 9 & 19 & 5 & 0 & 0 & \multirow{2}{*}{$<0.001$} \\
\hline Traditional & 3 & 6 & 5 & 6 & 1 & 38 & \\
\hline
\end{tabular}


Omar A. Fatani et al; Sch Int J Obstet Gynec, Jan. 2021; 4(1): 6-10

\begin{tabular}{|c|c|c|c|c|c|c|c|}
\hline \multicolumn{8}{|c|}{ Lacking self-discipline in home isolation } \\
\hline Online & 5 & 8 & 4 & 13 & 3 & 0 & \multirow{2}{*}{0.509} \\
\hline Traditional & 13 & 13 & 12 & 14 & 7 & 0 & \\
\hline \multicolumn{8}{|c|}{ Lacking learning materials in home isolation } \\
\hline Online & 3 & 8 & 7 & 14 & 1 & 0 & \multirow{2}{*}{0.513} \\
\hline Traditional & 7 & 10 & 12 & 22 & 8 & 0 & \\
\hline \multicolumn{8}{|c|}{ Lack of learning environment in home isolation } \\
\hline Online & 1 & 15 & 1 & 15 & 1 & 0 & \multirow{2}{*}{0.01} \\
\hline Traditional & 12 & 18 & 9 & 14 & 6 & 0 & \\
\hline \multicolumn{8}{|c|}{ Restriction of body language on screens } \\
\hline Online & 12 & 13 & 7 & 1 & 0 & 0 & 0.553 \\
\hline Traditional & 19 & 28 & 8 & 1 & 3 & 0 & \\
\hline \multicolumn{8}{|c|}{ Difficulty of Internet network availability } \\
\hline Online & 0 & 5 & 5 & 12 & 11 & 0 & \multirow{2}{*}{$<0.001$} \\
\hline Traditional & 0 & 1 & 0 & 11 & 9 & 38 & \\
\hline \multicolumn{8}{|c|}{ Online teaching is satisfying as face to face teaching } \\
\hline Online & 3 & 12 & 2 & 13 & 3 & 0 & \multirow{2}{*}{0.104} \\
\hline Traditional & 5 & 12 & 12 & 17 & 13 & 0 & \\
\hline \multicolumn{8}{|c|}{ Appropriateness of MINICEX tests for each objective } \\
\hline Online & 9 & 15 & 7 & 2 & 0 & 0 & \multirow{2}{*}{$<0.001$} \\
\hline Traditional & 0 & 0 & 0 & 0 & 0 & 59 & \\
\hline
\end{tabular}

Regarding satisfaction about e-learning, score and resources availability, a significant difference between groups was revealed. There is pattern of being more satisfaction in groups who had online teaching more than other group (Table-4).

\begin{tabular}{|c|c|c|c|c|c|c|c|}
\hline \multicolumn{8}{|c|}{ about e-learning, score and resources availability } \\
\hline \multirow[b]{2}{*}{ Group } & \multicolumn{6}{|c|}{ Responses (n) } & \multirow[b]{2}{*}{ p-value ${ }^{*}$} \\
\hline & $\begin{array}{c}\text { Very } \\
\text { Satisfied }\end{array}$ & Satisfied & Neutral & $\begin{array}{c}\text { Dis- } \\
\text { satisfied }\end{array}$ & $\begin{array}{c}\text { Very } \\
\text { Dissatisfied }\end{array}$ & $\begin{array}{c}\text { Not } \\
\text { Applicable }\end{array}$ & \\
\hline \multicolumn{8}{|c|}{ The level of satisfaction towards e-learning } \\
\hline Online & 6 & 15 & 5 & 6 & 1 & 0 & \multirow{2}{*}{$<0.001$} \\
\hline Traditional & 4 & 7 & 3 & 5 & 2 & 38 & \\
\hline \multicolumn{8}{|c|}{ Score in the discussion section for students in e-learning compared with traditional learning } \\
\hline Online & 6 & 12 & 10 & 5 & 0 & 0 & \multirow{2}{*}{$<0.001$} \\
\hline Traditional & 2 & 4 & 9 & 4 & 2 & 38 & \\
\hline \multicolumn{8}{|c|}{ Learning resources Availability } \\
\hline Online & 6 & 21 & 5 & 1 & 0 & 0 & \multirow{2}{*}{$<0.001$} \\
\hline Traditional & 3 & 7 & 8 & 1 & 2 & 38 & \\
\hline
\end{tabular}

Online course group showed increased rate of students complaining of increased stress, in comparison to traditional courses. There is significant difference in responses among groups (Table-5).

Table 5: Differences in frequencies of responses to questionnaire questions regarding difference in stress between styles of teaching

\begin{tabular}{|c|c|c|c|c|}
\hline \multicolumn{5}{|c|}{ stress detween styles or teacning } \\
\hline \multirow{2}{*}{ Group } & \multicolumn{3}{|c|}{ Online having Stress more than traditional } & \multirow{2}{*}{$\begin{array}{c}\text { p- } \\
\text { value }^{*}\end{array}$} \\
\hline & Yes & No & Not applicable & \\
\hline Online & 12 & 21 & 0 & \multirow{2}{*}{$<0.001$} \\
\hline Traditional & 4 & 17 & 38 & \\
\hline
\end{tabular}


Omar A. Fatani et al; Sch Int J Obstet Gynec, Jan. 2021; 4(1): 6-10

There is significant difference in between groups regarding rate of skipping online classes. It is more obvious in online group; however, it is trending that most of the students are not skipping the classes (Table-6).

\begin{tabular}{|l|c|c|c|c|c|c|}
\multicolumn{8}{|c|}{ Table 6: Differences in frequencies of responses to questionnaire questions regarding rate of } \\
skipping online classes
\end{tabular}

\section{DISCUSSION}

Our study indicates that out of 92 students, $54.3 \%$ of them used laptop for their e-learning. 56.5\% of the students prefer to combine both traditional and online classes while $28.2 \%$ prefer traditional classes only and only $15.2 \%$ prefer online classes only. Post Covid-19 outbreak students in Saudi Arabia were required to move All classes to online classes and temporarily bending clinical classes in medical college which is consider the most effective teaching in the clinical years of the college of medicine. Online learning was considered as fun teaching and learning compensation during this pandemic $70 \%$ found it interesting and enjoyable. However, $64 \%$ found it has limited student-teacher interactions therefore decreased learning effectiveness. Must of the students of the traditional group thought lacking self-discipline in home isolation which may affect negatively in learning outcomes. The internet connection wasn't an issue the majority of the students had stable internet connection Only $11 \%$ faced difficulties of internet network availability. Our study results also highlighted that students from both groups are not ready yet to consider e-learning as a better teaching tool and preferred for future learning which is different than the findings of a study conducted in Ghana. Revealing the result of students' satisfaction, the data shows most of the students were actively involved in online learning. $64 \%$ of the online classes group students were satisfied towards e-learning in the OB/GYN course and must of both groups satisfied online teaching as face to face teaching. $55 \%$ of them more satisfied of their score in the discussion section for students in e-learning compared to traditional learning. The material and assignments delivery in online learning was relatively good. The students thought that the delivered material and assignment were relevant to the course. Appropriate e-learning resources were available to guarantee the implementation of these enormous changes. More use of technological tools will enable the medical colleges to establish the active process of elearning. The lecturers also provided discussion sessions to answer the students' questions $82 \%$ of the students satisfied about the learning materials and resources availability. $64 \%$ of the students find online classes having less stress compared to there on the traditional. The majority of the students about $55 \%$ never skipped classes.

\section{REFERENCES}

1. Agarwal, S., \& Kaushik, J. S. (2020). Student's perception of online learning during COVID pandemic. Indian Journal of Pediatrics, 1.

2. Demuyakor, J. (2020). Coronavirus (COVID-19) and online learning in higher institutions of education: A survey of the perceptions of Ghanaian international students in China. Online Journal of Communication and Media Technologies, 10(3), e202018.

3. Abbasi, S., Ayoob, T., Malik, A., \& Memon, S. I. (2020). Perceptions of students regarding Elearning during Covid-19 at a private medical college. Pakistan Journal of Medical Sciences, 36(COVID19-S4).

4. Bao, W. (2019). Bridging the gap between research and practice: Identifying high-impact educational practices for Chinese undergraduate education. Peking University Education Review, 1, 105-129.

5. Bali, S., \& Liu, M. C. (2018, May). Students' perceptions toward online learning and face-toface learning courses. In Journal of Physics: Conference Series (Vol. 1108, No. 1).

6. Kwary, D. A. (2006). The comparison between the result of E-learning and traditional learning: a case study on reading IV subject at D-III in English language study program. Airlangga: Airlangga University.

7. Burac, M. A. P., Fernandez, J. M., Cruz, M. M. A., \& Cruz, J. D. (2019). Assessing the impact of e-learning system of higher education institution's instructors and students. MS\&E, 482(1), 012009.

8. Agarwal, S., \& Kaushik, J. S. (2020). Student's perception of online learning during COVID pandemic. Indian Journal of Pediatrics, 1.

9. Demuyakor, J. (2020). Coronavirus (COVID-19) and online learning in higher institutions of education: A survey of the perceptions of Ghanaian international students in China. Online Journal of Communication and Media Technologies, 10(3), e202018. 